UDC: 628.473

COBISS.SR-ID: 212210956

Original research paper

Acta Agriculturae Serbica, Vol. XIX, 38 (2014); 133-142

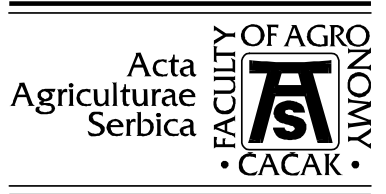

\title{
Processing biodegradable waste by applying aerobic digester EWA
}

\author{
Dragoslav Đokić, Zoran Lugić, Dragan Terzić, Goran Jevtić, Jasmina \\ Milenković \\ Institute for Forage Crops, 37251 Globoder, Kruševac, Republic Serbia
}

\section{Miroslav Húrka}

AGRO-EKO spol. s r.o., Obecni 811, 735 43, Albrechtice, Czech Republic

\section{Rade Stanisavljević}

Institute for Plant Protection and Environment, Teodora Drajzera 9, 11000

Beograd, Republic Serbia

\begin{abstract}
The paper presents research results obtained in the process of processing biodegradable wastes, resulting from agricultural production as well as municipal waste. Aerobic fermenter EWA (stationed within the Institute for Forage Crops GloboderKruševac) was using for this purpose, during the one month testing. Biodegradable material with different ratios of components was used for filling aerobic digester. EWA fermenter is certified device that is used to stabilize and hygienic disposal of biodegradable waste, including sewage sludge and animal products produced in accordance with European Union regulations. Fermenter is intended to be used for combustion in boilers for solid fuels with humidity of biomaterials below $30 \%$.
\end{abstract}

Keywords: aerobic fermenter, biodegradable waste. 


\section{Introduction}

By increasing the number of population in the world, industrialization, urbanization and economic prosperity, the amount of waste, both in developed countries and in developing countries. The industrially developed country, with a low percentage of the rural population, with a large production of goods and produce large amounts of waste, much higher than developing countries. The chemical composition of the waste is more complex, resulting in the damage to human health and the environment. There is a need of finding a suitable way of processing biodegradable waste. Biodegradable waste is waste that is suitable for anaerobic or aerobic decomposition, such as products from agricultural and forestry production, food, garden waste, paper and cardboard. Anaerobic digestion is a process in which biodegradable material decomposes without the presence of oxygen. According to the morphological composition of municipal waste in the Republic of Serbia, the largest part of the waste is biodegradable waste $(31.0 \%)$, garden waste $(11.9 \%)$, cardboard $(7.5 \%)$ and paper $(7.3 \%)$ which makes total of $54.7 \%$ of the waste that can be decompose (Statistical Office of the Republic of Serbia 2012).

According to the "Law on Waste Management, Republic of Serbia", the "Law on waste materials" and "Law on environmental protection of the Republic of Serbia" waste is any substance or object which the owner removes or intends or it must to remove, which is classified in the category of waste regulated by special regulations (Official Gazette, 1996a, 1996b, 2004, 2005, 2009). Communal waste constitutes household waste resulting in residential buildings, official buildings, stores, waste from public areas (mostly stable organic matter as a "green waste", waste plants, cardboard boxes, etc., a part of the organic unstable substances such waste food, animal residues), (http://www.cqm.rs/2009/pdf/4/10.pdf). Communal waste management includes the functions of collection, transportation, recycling, reuse, treatment and disposal of communal solid waste. The formation of municipal waste depends on the level of industrial development, living standards, lifestyles, social environment, consumption, etc. (Nešić 2010). Applied different kinds of living microorganisms, bacteria, fungi, algae and protozoa, which under aerobic or anaerobic conditions may remove, transform or convert organic compounds into inorganic (Panić 2010). Some parts of the waste can pose a great source of energy. From the process of composting the organic waste can be obtained by a material that is similar to humus. The organic waste material which is to be returned to nature. From organic waste to anaerobic digestion process can get fuel gas and organic fertilizer (Ilić and Trumić 2006; Marković 2009).

The degree of aeration during composting is important because the amount of air present depends on whether the compost to occur aerobic processes (preferred) or anaerobic processes. If there is no air, anaerobic microorganisms 
will be developed. They are mainly caused by the process of putrefaction, which develops an unpleasant odor and form useless mass of organic waste for composting (Mirecki 2007). Composting mainly backyard waste in the form of cut grass, leaves, parts bushes and trees, food waste, paper, cardboard, organic fractions, agricultural wastes like plant residues, animal manure (Zámanek et al. 2010).

Upon completion of the composting pile of compost that gets reduced volume with $20 \%-60 \%$. Moisture content is below $40 \%$, and the mass is reduced by $50 \%$. The $\mathrm{pH}$ value of the obtained compost is about 7 , respectively neutral, and the ratio of carbon to nitrogen $(\mathrm{C}: \mathrm{N})$ should be less than 80:1. Unpleasant odor that occurs in the starting material change in odor that reminds of the smell of soil (Marjanović et al. 2008). The composition of the compost should not be located impurities such as visible particles of metals, plastics and glass and coliform bacteria such as Salmonella ssp., E. coli, Enterococcae, etc. (Barth et al. 2008).

The aim of the study was the practical application of aerobic fermenter EWA and testing the quality of the product obtained from biodegradable materials.

\section{Materials and methods}

The processing of biodegradable waste at the Institute for forage crops, Globoder-Kruševac in period from 17.10.2013. to 19.11.2013. The aerobic fermenter EWA (Ecological Waste Apparatus) Czech production was used. Czech Republic, which is a member of the EU in its law, has regulations for dealing with biodegradable waste (Sbírka zákonů 2008).

Aerobic fermenter EWA (Fig. 1) is certified device for processing biodegradable waste (BDW), including sewage sludge and animal products in accordance with decree EU (1069/2009 EC; 1774/2002). The device consists of a thermally insulated space, the air of the injector system to blow air intensively. System for filling mass consists of a segment of the floor conveyor, and which is located inside the fermenter, and an integrated device for charging and discharging. To run segmented floor used hydraulic cylinders which receive power from the hydraulic pump. Work fermenter is automatic whereby throughout the process temperature is measured at 16 points. Control of the work process, and determining the mode is done in the industrial touch screen display computer that is built into the fermenter. Blowing air into the digester is done fan (http://www.agro-eko.cz/cz/ke-stazeni/).

The principle of work of the fermenter is composed of chopped and mixed inserting a biodegradable material to the fermenter. The optimum moisture of the material is $50-60 \%$, wherein the inserting the air activate work of aerobic bacteria. Also to intensifying the mixing of the mass is done during the metabolic activity of which leads to an increase in temperature and an increase 
of bacteria. This speeds up the composting process, whereby complex organic materials decompose and transform into another. At temperatures above $70^{\circ} \mathrm{C}$ is gradually denature the proteins. High temperature for a certain period of work caused by the inactivation of the bacteria present and pathogenic organisms (viruses, bacteria, yeasts, fungi, protozoa and viruses). Due to the high temperature reduce the number of microorganisms and weed seeds lose their germination ability. After discharging the fermenter resulting material was analyzed in the chemical and microbiology laboratory to determine the chemical composition and the presence of coliform bacteria.

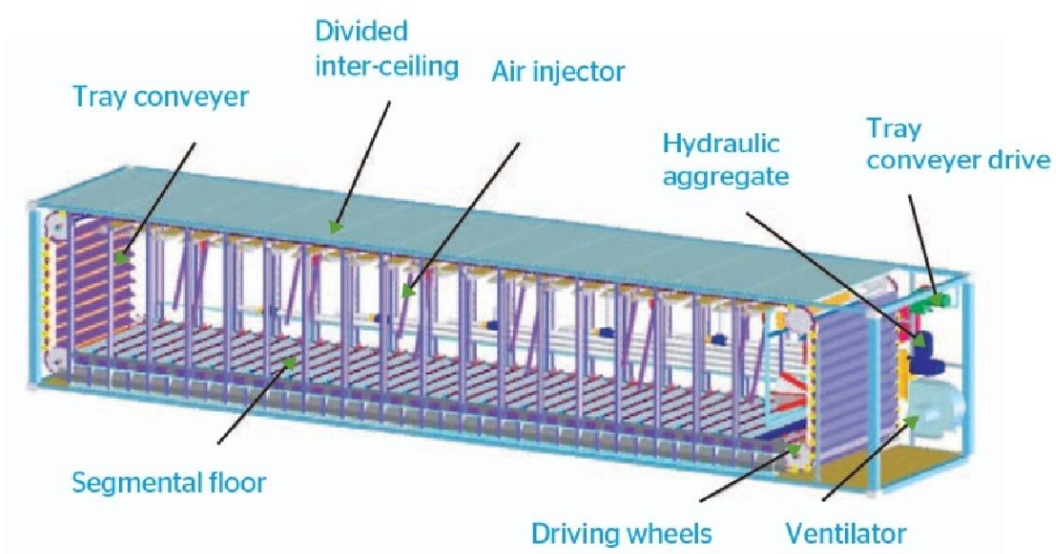

Figure 1. Cross section on aerobic fermenter EWA

Mulch-compost is obtained by controlled aerobic fermentation (thermophilic fermentation). It is a mixture of agricultural and forest biomass with biodegradable waste. Its structure is fibrous, crumbly with noticeable pieces of biomass (bark, wood chips, straw). The color is brown, brown-gray and smells like mushrooms or wet wood. The basic technical characteristics of aerobic fermenter EWA were shown in Table 1.

Table 1. Technical parameters of aerobic fermenter EWA (Agro-eko)

\begin{tabular}{lc}
\hline Length $(\mathrm{mm})$ & 12192 \\
Width $(\mathrm{mm})$ & 2438 \\
Height $(\mathrm{mm})$ & 2896 \\
Empty fermenter weight $(\mathrm{kg})$ & 14800 \\
Maximum weight of the full fermenter $(\mathrm{kg})$ & 32000 \\
Working zone volume $\left(\mathrm{m}^{3}\right)$ & 36 \\
Load weight $(\mathrm{t})$ & $10-17$ \\
Electric supply $(\mathrm{kW})$ & 15 \\
\hline
\end{tabular}


The operation cycle of the fermenter EWA is controlled on the basis of operation reading of conditions and values which characterize the aerobic fermentation. The intelligent control is based on measuring of these values: fill temperature in the whole section and oxygen content in the exhaust gas. Current values are recorded and assessed by an industrial computer.

\section{Results and Discussion}

Two compositions of the fermenter feeding EWA during examination were presented in Table 2. Charging was carried out with biodegradable material that is obtained from agricultural production from livestock around of Kruševac (chicken voiding), straw cereals, waste of public-utility Company in Kruševac (plant waste in the form of leaves, cut grass, branches). The digestate was produced from methane to produce electricity from dairy "Lazar" in Blace. Part of the biomass was obtained from economy of the Institute for forage crops. Plant mass was previously chopped in chopper-blower and then mixed with Bobcat loader in certain proportions and transporters inserted into the fermenter. Depending on the composition of the components inside the fermenter, and the total weight of the fermentation process is differently ranged. The fermentation process during filling 081310032 was four days (28.10. - 31.10.). Mass charging was $27.9 \mathrm{t}$. The fermentation of the process in charge of 081311033 was 7 days (01.11. - 07.11.). Mass charging was 16.4 t. The total mass of charging was 44,3 t.

Table 2. The composition of the fermenter EWA charging numbers 081310032 and 081311033

\begin{tabular}{clccc} 
Charging & Number of charging & 081310032 & 081311033 & $\Sigma$ \\
\hline Digestate & \multicolumn{1}{c}{ Date } & $28.10 .-31.10$. & $01.11 .-07.11$. & \\
\hline & Digestate - Blace & $100.00 \%$ & $78.70 \%$ & \\
Chicken voiding & $0.00 \%$ & $10.40 \%$ & \\
Straw cereals & $0.00 \%$ & $2.40 \%$ & \\
Grass & $0.00 \%$ & $4.90 \%$ & \\
Plant waste & $0.00 \%$ & $3.60 \%$ & \\
$\Sigma$ & $100.00 \%$ & $100.0 \%$ & \\
& & & 44, \\
Mass (t) & 27.90 & 16.40 & 3 \\
\hline
\end{tabular}

During operation, all the relevant parameters of work were monitored. The movement of the charging temperature during the fermentation process, and the total operation time are presented in Figure 2. Data were obtained from the 
computer that controls the whole process of work, and can be seen charging ratio of all components (digestate $78.70 \%$, chicken voiding $10.40 \%$, straw cereals $2.40 \%, 4.90 \%$ grass and plant waste $3.60 \%$ ). Measuring the temperature of fermentation is conducted at sixteen locations within the fermenter at four different heights (four lines of different colors on the chart). The maximum temperature during the fermentation was more than $70^{\circ} \mathrm{C}$, which caused protein denaturation and inactivation of bacteria and pathogenic organisms. The ability of seed germination of weed loses at these temperatures.

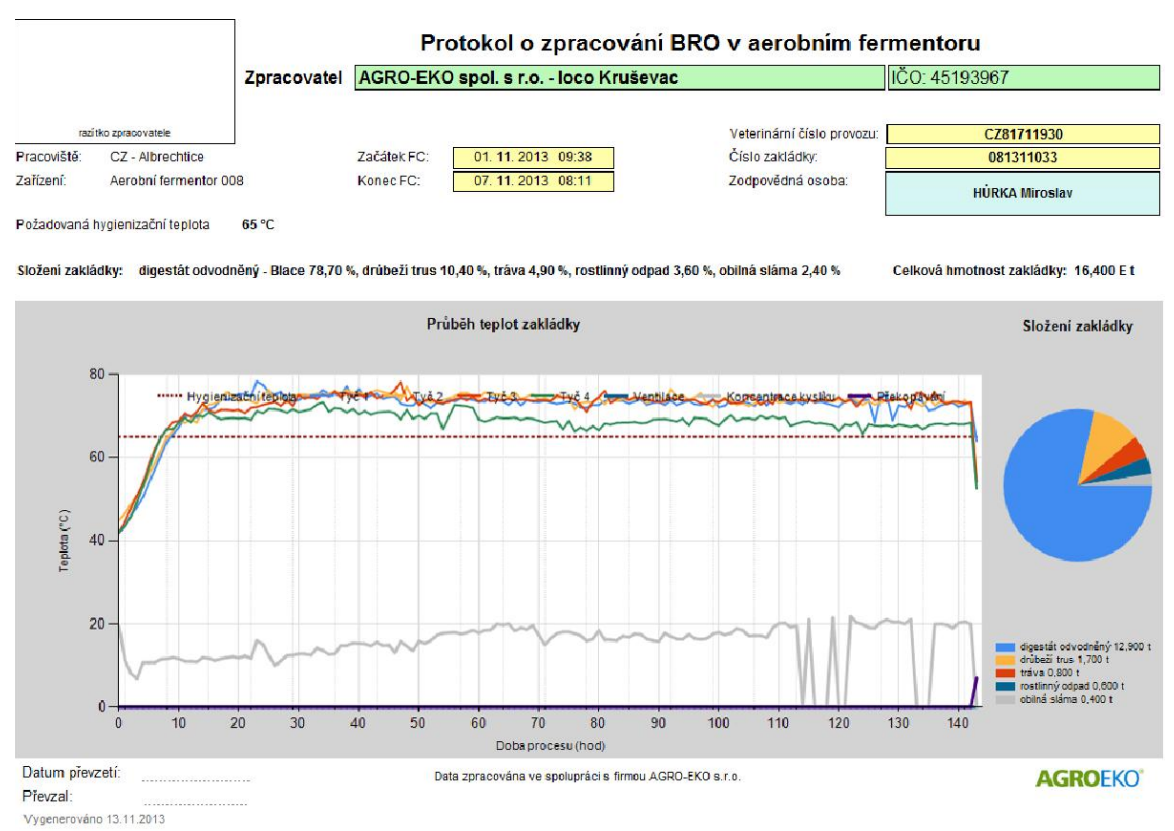

Figure 2. Display of temperature, time of fermentation and the charging ratio of the components

In the Czech Republic in the authorized chemical and microbiological laboratory in Albrechtice was done the chemical analysis (Table 3), and microbiological analysis (Table 4 ) of obtained material.

Table 4. shows the microbiological composition of the sample 081310033, which is also done in an approved chemical and microbiological laboratory in Albrechtice the particular methodology which is compliant with the Regulation of the European Parliament (1774/2002).

During operation, test tubes are inserted into the fermenter with seeds of corn, alfalfa and grass to determine the seed germination after the fermentation process. After the fermentation process there was not seed germination. 
Table 3. The chemical composition of the digestion number 081310033

\begin{tabular}{|c|c|c|c|}
\hline \multicolumn{2}{|l|}{ Chemical analysis } & \multicolumn{2}{|r|}{ Number of samples 081310033} \\
\hline Composition & Result & Measure unit & Method \\
\hline Arsenic & 3.65 & $\mathrm{mg} / \mathrm{kg}$ in dry matter & SOP 02C (ČSN EN ISO 15586) A \\
\hline Cadmium & 0.16 & $\mathrm{mg} / \mathrm{kg}$ in dry matter & SOP 02 C (ČSN EN ISO 5961) A \\
\hline Chrome & 41.7 & $\mathrm{mg} / \mathrm{kg}$ in dry matter & SOP 23 C (ČSN EN 1233) A \\
\hline Copperr & 32.2 & $\mathrm{mg} / \mathrm{kg}$ in dry matter & SOP 23 C (ČSN ISO 8288) A \\
\hline Mercury & 0.052 & $\mathrm{mg} / \mathrm{kg}$ in dry matter & SOP 03 (ČSN 465735, ČSN 721227) A \\
\hline Nickel & 38.7 & $\mathrm{mg} / \mathrm{kg}$ in dry matter & SOP 23 C (ČSN ISO 8288) A \\
\hline Plumb & 21.0 & $\mathrm{mg} / \mathrm{kg}$ in dry matter & SOP 23 C (ČSN ISO 8288) A \\
\hline Zinc & 125 & $\mathrm{mg} / \mathrm{kg}$ in dry matter & SOP 23 C (ČSN ISO 8288) A \\
\hline Calcium & 28.4 & $\mathrm{~g} / \mathrm{kg}$ in dry matter & SOP 23 C (ČSN ISO 8288) A \\
\hline Magnesium & 5.99 & $\mathrm{~g} / \mathrm{kg}$ in dry matter & SOP 23 C (ČSN ISO 7980) A \\
\hline Potassium & 18.2 & $\mathrm{~g} / \mathrm{kg}$ in dry matter & SOP 28 B (JPP - UKZUZ, Brno) A \\
\hline Phosphorus & 5.50 & $\mathrm{~g} / \mathrm{kg}$ in dry matter & SOP 62 A (JPP - UKZUZ, Brno) A \\
\hline Total dry matter & 32.55 & $\%$ & SOP 32 (ČSN EN 12879) A \\
\hline $\mathrm{pH}\left(\mathrm{H}_{2} \mathrm{O}\right)$ & 8.46 & & SOP 44 (JPP - UKZUZ, Brno) A \\
\hline Flammable substances & 74.1 & $\%$ in dry matter & SOP 32 (ČSN EN 12879) A \\
\hline Ratio C:N & 19 & & SOP 85 (JPP - UKZUZ, Brno) N \\
\hline Total nitrogen & 1.98 & $\%$ in dry matter & SOP 61 A (JPP - UKZUZ, Brno) A \\
\hline
\end{tabular}

Table 4. Microbiological composition of the digestion number 081310033

\begin{tabular}{|c|c|c|c|}
\hline \multicolumn{4}{|c|}{ Microbiological analysis of samples number 081310033} \\
\hline Composition & Result & Measure unit & Method \\
\hline Enterococcae & $<5 \times 10^{1}$ & $\mathrm{KTJ} / \mathrm{g} \mathrm{DM}{ }^{*}$ & $\begin{array}{l}\text { SOP } 103 \text { A (ČSN EN ISO } \\
7899-2) A\end{array}$ \\
\hline $\begin{array}{l}\text { Thermotolerant } \\
\text { coliform bacteria }\end{array}$ & $<5 \times 10^{1}$ & $\mathrm{KTJ} / \mathrm{g} \mathrm{DM}^{*}$ & SOP 102 A (ČSN 757837) A \\
\hline Salmonella ssp. & Negative & ----- & $\begin{array}{l}\text { SOP } 117 \text { A (ČSN EN ISO } \\
6579) \text { A }\end{array}$ \\
\hline Test for Salmonella & Negative & ---- & $\begin{array}{l}\text { SOP } 117 \text { A (ČSN EN ISO } \\
6579) \text { A }\end{array}$ \\
\hline
\end{tabular}

$\mathrm{DM}^{*}$ - Dry Matter 


\section{Conclusion}

Man is the only being on earth which creates waste. Polluting increases with the creation of illegal dump sites with a huge amount of inorganic and organic wastes. Waste is considered one of the most important environmental problems of the modern world due to the increasing amount and harmfulness to the environment.

Processing of biodegradable waste into compost is one way to solve this problem. In view of the landfill directive and the EU prohibition disposal of biodegradable waste to landfill, composting has gained importance as an alternative treatment to biodegradable waste.

One of the solutions for the processing of biodegradable agricultural, municipal and forestry waste is the use of aerobic fermenter EWA which showed very good results in one month testing period. Fermenter can be easily connected to the electrical grid and consumes small amount of power. It is easy to transport and handle. Inspection and monitoring of digester is possible over the Internet. All results obtained showed that the material obtained is not a pathogen, or had them within the allowed limits. Tests shows that the temperature within the fermenter destroyed the seed germination. Using these devices can reduce the amount of waste sent to landfill, reducing the unpleasant smells (stabilization) and eliminate the pathogens (hygienization).

\section{Acknowledgements}

Research was financed by the Ministry of Education, Science and Technological Development of Republic of Serbia, Projects: TR-31057 and Eureka E! 6742WINEREST financed by The European Union.

\section{References}

Agro-eko, (2013): http://www.agro-eko.cz/cz/ke-stazeni/

Barth, J., Amlinger, F., Favoino, E., Siebert, Stefanie, Kehres, B., Gottschall, R. Bieker, M., Löbig, Anita, Bidlingmaier, W. (2008): Compost production and use in the EU, ORBIT e.V. / European Compost Network ECN, Weimar, Germany.

Ilić, Marina, Trumić, M. (2006): Upravljanje komunalnim otpadom u Srbijistanje i perspektive, Zbornik radova, XIV Naučno-stručni skup o prirodnim vrednostima i zaštiti životne sredine, Sokobanja, Srbija i Crna Gora, 585-596.

Jovičić, N., Petrović, Danijela, Jaćimović, M., Jovičić Gordana, Gordić, D., Babić, M. Tehno-ekonomska analiza postrojenja za kompostiranje organskog otpada grada Kragujevca: http://www.cqm.rs/2009/pdf/4/10.pdf 
Marjanović, V., Mančić, A., Cvejić, M. (2008): Kompostiranje. Ako više znam, više mogu da štedim, Demokratska stranka/istraživačko-izdavački centar, Beograd.

Mark ović, N . (2009): Kućni otpad-Od problema do rešenja, Štampanje je omogućila Misija OEBS u Srbiji, Beograd.

Mirecki, Nataša (2007): Kompostiranje, Priručnik. Izdavač: NVO, Proizvodnja Zdrave hrane, SIDA

Nařízení evropskèho parlamentu a rady 2002. č. 1774/2002 ze 3. října 2002, Česká Republika.

Neš ić, B . (2010): Upravljanje komunalnim otpadom i p ote n cijali za reciklažu na primeru južne i jugoistočne Srbije, Protecta, Niš.

Panić, Milena (2010): Geografski institut "Jovan Cvijić", Srp ska akademija nauka i umetnosti, Upravljanje opasnim otpadom-planiranje, organizacija, funkcionisanje sistema, posebna izdanja, knjiga 80, Beograd: http:/www.gi.sanu.ac.rs.

Republički zavod za statistiku (2012): Statistika otpad i upravljanje otpadom u Republici Srbiji, 2008-2010, Beograd, Republika Srbija: www.stat.gov.rs

Sbírka zakonů, (2008): č. 341 / 2008, Česká Republika.

Službeni. glasnik RS (1996a): Zakon o postupanju sa otpadnim materijalima, br. 25/96.

Službeni. glasnik RS (1996b): Zakon o postupanju sa otpadnim materijalima, br. 26/96.

Službeni glasnik RS (2004): Zakon o zaštiti životne sredine Republike Srbije, br 135/04: www.sepa.gov.rs

Službeni. glasnik RS (2005): Zakon o postupanju sa otpadnim materijalima, br. 101/2005

Službeni glasnik RS (2009): Zakon o upravljanju otpadom Republike Srbije, br. 36/2009.

Úřední věstník Evropské unie (2009): Nařizení evropskèho parlamentu a rady (ES) č. 1069/2009, ze dne 21. ř́ijna 2009, Česká Republika.

Zámanek, P., Burg, P., Kollarová, Mária, Marešová, Karoliná, Pliva, P. (2010): VÚZT, v.v.i., Biologicky rozložitelné odpady a kompostováni, Praha. 


\title{
PRERADA BIOLOŠKI RAZGRADIVOG OTPADA PRIMENOM AEROBNOG FERMENTATORA EWA
}

\author{
Dragoslav Đokić, Zoran Lugić, Dragan Terzić, Goran Jevtić, Jasmina \\ Milenković \\ Institut za krmno bilje, 37251 Globoder, Kruševac, Republika Srbija
}

\author{
Miroslav Húrka \\ AGRO-EKO spol. s r.o., Obecni 811, 735 43, Albrechtice, Češka \\ Republika \\ Rade Stanisavljević \\ Institut za zaštitu bilja i životnu sredinu, Teodora Drajzera 9, 11000 \\ Beograd, Republika Srbija
}

\begin{abstract}
Rezime
Rad prikazuje rezultate istraživanja koji su dobijeni pri procesu prerade biološki razgradivog otpada dobijenog iz poljoprivredne proizvodnje, kao i komunalnog otpada primenom aerobnog fermentatora EWA (češke proizvodnje stacioniranog u krugu Instituta za krmno bilje u Globoderu-Kruševcu). U toku jednomesečnog ispitivanja vršeno je punjenje aerobnog fermentatora biološki razgradivim materijalom s različitim odnosom komponenata. EWA fermentator je sertifikovan uređaj koji se koristi za stabilizaciju i higijenizaciju biorazgradivog otpada, uključujući kanalizacioni mulj i proizvode životinjskog porekla proizveden u skladu sa propisima Evropske Unije. Fermentator može da se koristi i za dobijenje biogoriva namenjenog za sagorevanje u kotlovima za čvrsta goriva pri čemu je vlažnost biomaterijala koji se koristi ispod $30 \%$.
\end{abstract}

Ključne reči: aerobni fermentator, biološki razgradljiv otpad. 